RESEARCH ARTICLE

\title{
HOW GOVERNMENT STRENGTHENS THE STREET VENDORS: ANALYSIS OF THE ROLE OF BREBES DISTRICT GOVERNMENT
}

\author{
Akhmad Ghofar Ismail ${ }_{\varpi}$, Ridwanto Ardi Kusumo² \\ ${ }^{1}$ Leader Store, Business Company, Brebes, Central Java, Indonesia \\ ${ }^{2}$ Notary and Official Certifier of Title Deeds, Kendal Regency, Indonesia \\ $\triangle$ dearesll1@gmail.com
}

HOW TO CITE:

Ismail, A.G., \& Kusumo, R.A. (2020). How Government Strengthens the Street Vendors: Analysis of the Role of Brebes District Government. Journal of Law and Legal Reform, 1(1), 49-60. DOI: https://doi.org/10.15294/jllr.vlil.35408

\section{ABSTRACT}

The empowerment of street vendors in an area, if appropriately managed, will be able to improve the economy of the community and the local government. It is the duty of the local government. This study aims to find out the efforts and impacts of street vendors' empowerment by the Brebes Regency government. The results showed that: (1) street vendors' empowerment efforts carried out by the Brebes Regency Government were reasonable, but it would be better if street vendors' empowerment efforts had special regional regulations related to street vendors' empowerment. (2) The impact of empowerment by the Brebes Regency Government is divided into two aspects, namely social and economic issues. Common elements, for example, the formation of street vendor associations, a more organized environment, in financial aspects, for instance increasing street vendors' income and increasing the income of Brebes Regency.

Keywords: Street Vendors; Empowerment; Local Government; Policy 


\section{TABLE OF CONTENTS}

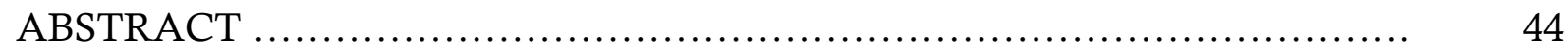

TABLE OF CONTENTS …................................................... 44

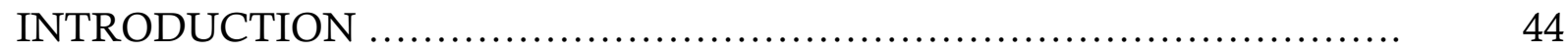

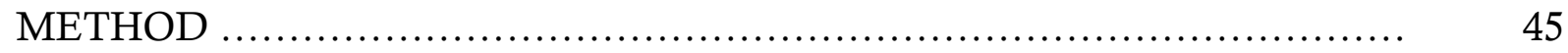

STRENGTHENING STREETS VENDORS BY PROPER POLICY ............ 45

I. BREBES REGENCY GOVERNMENT EFFORTS IN STRENGTHENING STREET VENDORS …............................. 37

A. Policy and Empowerment .............................................. 45

B. Social Assistances for Street Vendors ................................ 46

II. THE IMPACT OF STREET VENDORS EMPOWERMENT BY THE BREBES REGENCY GOVERNMENT ..................................... 48

A. Human Development or Bina Manusia ..................................... 48

B. Business Development or Bina Usaha .................................... 48

C. Community Development or Bina Lingkungan ............................. 49

CONCLUSION …........................................................... 50

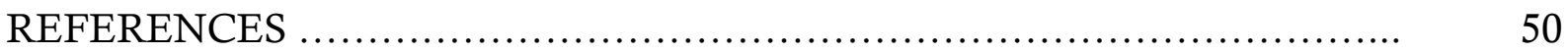

\section{INTRODUCTION}

Development is the process of changing from a less favorable condition to a better situation. Growth in the economy in an area cannot be separated from the informal sector, namely Street Vendors (Lata, Walters, \& Roitman, 2019; Arifin, 2019). Street Vendors are economic activities in the form of the informal sector that open businesses in the production and sale of goods and services using relatively small capital and occupy public spaces that are considered strategic (Haryono in the Yusdi, 2011:12).

Street vendors, if managed properly, can improve the economy of the community and local government (Lee, Lu, Yang, \& Chang, 2019). In empowering street vendors in Indonesia, referring to Presidential Regulation Number 125 of 2012 concerning Coordination of Structuring and Empowering Street Vendors and Regulation of the Minister of Home Affairs Number 41 of 2012 concerning guidelines for structuring street vendors, Street Vendors have the right to be considered by local governments.

Street Vendors are considered to create a lot of problems in addition to city spatial planning, for example, the problem of garbage or waste generated by street vendors, besides the traffic jams that are generated because they are needed on the sidewalk or in that area (Kearney, Shemla, van Knippenberg, \& Scholz, 2019).

The Brebes Regency Government in its efforts to empower street vendors does not have clear guidelines or references. This is because the Brebes Regency government does not have specific regional regulations regarding street vendors. In the absence of this regional regulation, the empowerment carried out by the Brebes 
Regency government is less than optimal. In addition, the lack of public areas in the Brebes Regency has an uneven distribution of street vendors in the Brebes Regency. Street vendors prefer to sell on the side of the road if it is not monitored by the government, this happens on Veteran Street, Brebes District.

\section{METHOD}

The method used in this research is descriptive qualitative by taking research locations in Brebes Regency, Brebes Regency. Brebes District was chosen as the location of the study because the Brebes local government provided assistance in the form of shelters at only a few points in the Brebes sub-district by the Brebes Regency government. Researchers examined at several points containing shelters in Brebes Regency.

The primary data source in this study was the result of an interview with street vendors who received shelters, Cooperatives and Small and Medium Enterprise Office dan Civil Service Police. Secondary data are documents obtained from Cooperatives and Small and Medium Enterprise Office and Civil Service Police related policies relating to empowering street vendors. Data collection tools and techniques used in this study include observation, interviews, and documentation (Higgins et al., 2019). The validity test used in this study uses source triangulation (Gharaei, Karimi, \& Hoseini Shekarabi, 2019). Data analysis techniques use interactive data analysis which includes data reduction, data presentation, and drawing conclusions (Faiola, Papautsky, \& Isola, 2019; Arifin, Waspiah, \& Latifiani, 2018).

\section{STRENGTHENING STREETS VENDORS BY PROPER POLICY}

\section{BREBES REGENCY GOVERNMENT EFFORTS IN STRENGTHENING STREET VENDORS}

\section{A. Policy and Empowerment}

Community policy is an activity carried out by the government to meet the needs of the community (Clough Marinaro, 2019). Public policy is determined by the government. The policy level can be at the general level, implementation level, and technical level (Crittenden, Crittenden, \& Ajjan, 2019). A policy must also be possessed by no importance. Not important from the policy, namely (l) policy objectives, (2) problems, (3) guarantees (demand), and (4) impact or results (Handoyo, 2008: 1; Jhody, 2017).

Conceptually empowerment or empowerment comes from the word "power" (power or empowerment). Therefore, the main idea of empowerment is in contact with the concept of power (Suharto, 20017: 57). Empowerment is a way by which 
people, organizations and communities are directed to be able to dominate (rule over) their lives (Corwin \& Johnson, 2019).

According to Suharto (2017: 93), social assistance is a strategy that really determines the success of community empowerment programs. In accordance with the principle of social work, which is "helping people to be able to help themselves," community empowerment is very concerned about the importance of strong public participation (Cheung, Davies, \& Trück, 2019).

Street vendors are all people who carry out business activities with the intention of obtaining legitimate income, are carried out on a non-permanent basis, with limited ability, located in places or consumer centers, do not have a business license (Alma, 2017: 157). The characteristics of street vendors are:

a. Business activities, not well-organized

b. Do not have a business license

c. Irregular in business activities, both in terms of place of business and working hours

d. Crowded on sidewalks, or protocol road edges, in centers where many people are crowded

e. Peddling his wares while shouting, sometimes running toward consumers (Ojeda \& Pino, 2019).

The problem of street vendors is a problem that cannot be separated from the problem of population explosion from urban growth(Cheong, Yammarino, Dionne, Spain, \& Tsai, 2019). Most of them belong to the lower economic layers of society, in the economic and social structure. The distinguishing characteristic of this group is their irregularity peddling their wares, which legally violates the applicable provisions (Pembuain, Priyanto, \& Suparma, 2019).

In the context of efforts to empower street vendors, the Government of the Republic of Indonesia issued regulations of the President of the Republic of Indonesia Number 125 of 2012 concerning Coordination of Structuring and Empowering Street Vendors and Regulation of the Minister of Home Affairs No.41 of 2012 concerning guidelines for structuring street vendors.

Brebes Regency in terms of empowering street vendors in the district of Brebes received assistance from the Ministry of Cooperatives and Micro Enterprises of the Republic of Indonesia in an effort to empower street vendors by providing buildings or shelter. This construction cost 400 million rupiah with an allocation of 50 shelters built at several points in the District of Brebes.

Efforts to empower street vendors must be monitored and directed, in terms of empowering street vendors in Brebes it is the obligation of the Brebes Regency government. The Brebes Regency Government in its efforts to empower street vendors cannot relinquish responsibility for monitoring and directing street vendors after empowering. Referring to Suharto (2017), that social assistance is centered on tasks or functions that can be abbreviated in the acronym 4P: enabling, empowering, protecting, and supporting. 


\section{B. Social Assistances for Street Vendors}

\section{Enabling}

It is a function related to motivating and opportunities for the community. The number of social worker tasks associated with this function includes setting an example, conducting mediation and negotiation, building joint consensus, and managing resources (Kaasinen et al., 2019). Social workers are called to be able to mobilize and coordinate these resources so that they can be reached by clients (Yakubu Madaki \& Bavorova, 2019).

The implementation of the empowerment of street vendors by the Brebes Regency government accommodates and provides space for street vendors to discuss and channel their aspirations every two months which are initiated Brebes Civil Service Police. To easier accommodate street vendors, Civil Service Police forming associations of street vendors in Brebes District. Besides the street vendors must be members of the cooperative namely Makmur Jaya. In addition, empowerment efforts from Cooperatives and Small and Medium Enterprise Office conduct coaching which in 2017 was conducted in three places in Brebes Regency, one of which was in Brebes District. However, this coaching is not specific to street vendors but for all traders including street vendors.

\section{Empowering}

This function is related to education and training to strengthen community capacity. The facilitator plays an active role as an agent who provides positive and directive input based on the knowledge and experience of the community he is assisting (Peng et al., 2019). Raise public awareness, convey information, conduct confrontations, organize forms of reinforcement. As a function in social assistance, education refers more to a process of activity, rather than as a result of an activity (Tatebe et al., 2019).

The implementation of empowering street vendors in Brebes District by the Brebes Regency Government through Civil Service Police in the association of street vendors is facilitated to gather and voice their aspirations related to regulations or submit complaints regarding their trading activities. Not only when discussing routine meetings of street vendors, but Civil Service Police also conducts counseling, guidance, and direction to street vendors at certain times according to the schedule of activities of Civil Service Police in Brebes Regency. As well as street vendors who have become members of cooperatives specifically for street vendors and traders in the traditional Brebes market namely Makmur Jaya cooperatives will get further strengthening.

\section{Protecting}

This function is related to the interaction between facilitators and external institutions on behalf of and in the interests of the assisted communities (Shiningeni, Chimwamurombe, Shilangale, \& Misihairabgwi, 2019). Social workers can be tasked with finding resources, defending, using the media, improving community relations, and building networks. The protection function also involves the task of social 
workers as consultants, people who can be consulted in the problem-solving process (Soon, 2019).

The protection function in empowering street vendors in Brebes District by Brebes Regency is carried out by the Civil Service Police and the Brebes Regency Police (POLSEK). This protection effort was realized with the presence of patrol activities carried out by both the Brebes Regency Police and the Civil Service Police. In addition, street vendors who feel the thugs or other disorders can report it on social media Civil Service Police and Brebes Regency Police there. In addition, complaints can be made through the telephone numbers of the two agencies.

\section{Supporting}

This refers to the application of practical skills that can support positive change in society (Richardson-Ngwenya, Restrepo, Fernández, \& Kaufmann, 2019). Assistance is required not only to be a change manager who organizes groups but also to be able to carry out technical tasks in accordance with a variety of basic skills such as conducting social analysis, managing group dynamics, establishing relationships, negotiating, communicating, and seeking and managing sources of funds (Prabhu et al., 2019).

In the effort to empower street vendors carried out by the Brebes Regency government in the support function, including becoming a member of the Makmur Jaya cooperative, becoming a member of the street vendor community in accordance with the area they sell. In these cooperatives and associations, street vendors can communicate, exchange ideas, and discuss their experiences while selling. It is expected that with this interaction that occurs between street vendors they can add knowledge, new experiences, and information that makes the street vendors can be more developed.

\section{THE IMPACT OF STREET VENDORS EMPOWERMENT BY THE BREBES REGENCY GOVERNMENT}

In the practice of community empowerment carried out by many parties, it is often limited to economic empowerment in the context of poverty alleviation or poverty alleviation. Therefore, community empowerment activities are always carried out in the form of developing productive activities to increase income. About this, Sumadyo in Mardikanto (2017: 113) formulated three main efforts in every community empowerment, which he called Tri Bina: Human Development (Bina Manusia), Business Development (Bina Usaha), and Community Development (Bina Lingkungan).

\section{A. Human Development or Bina Manusia}

Human development is the first and foremost effort that must be considered in every effort to empower the community. This is based on the understanding that the purpose of development is to improve the quality of life or human welfare(Carroll, 2019). In addition, in the science of human management occupies the most unique 
element. Because, in addition to being one of the resources as well as an actor or manager of management itself. Human development is all activities that include efforts to strengthen/develop capacity (Carmi, Alsayegh, \& Zoubi, 2019).

Human development conducted by the Brebes Regency government related to the empowerment of street vendors based on interviews conducted by researchers with street vendors and related agencies is the formation of a community of traders in the District of Brebes, especially for street vendors. There are 10 associations of street hawkers in the Brebes Sub-district which were initiated by the Civil Service Police Brebes.

In the association, Civil Service Police Brebes also holds regular meetings every two months. With the formation of the street vendor community in Brebes District, this opens space for street vendors to discuss, exchange ideas and experience among street vendors. With the positive things that are expected to increase the creativity of street vendors in the future.

\section{B. Business Development or Bina Usaha}

Business development becomes an important effort in every empowerment because human development without providing an impact or benefit for improving welfare will not sell and even increase disappointment (Bergeron, Noskoff, Hayakawa, $\&$ Frediani, 2019). Conversely, only human development that is able to provide an impact or benefit for the improvement of welfare will be sold or get support in the form of community participation (Andersen \& Pitkänen, 2019).

Business development carried out by the Brebes Regency government related to empowering street vendors in Brebes District according to the results of the study was the formation of cooperatives for street vendors named Makmur Jaya cooperatives. According to the results of research with related agencies, this cooperative is intended for street vendors. The new street vendors who want to get a shelter must register with the street vendor cooperatives that sell in the District of Brebes. Based on the results of researchers' interviews with street vendors, the researchers felt that the Brebes Regency government in an effort to empower street vendors was not optimal. The government should conduct socialization and training for street vendors. This was done with the aim of increasing the creativity of street vendors in selling. In addition, routine meetings of street vendors should be held once a month so that they can coordinate faster.

From the results of interviews with street vendors conducted by researchers in the field, researchers found information that street vendors also needed capital assistance to develop their businesses. The business capital assistance should be given by the government so that street vendors can develop their businesses.

With the development of the street vendors business, it will increase the income of street vendors, besides increasing the income of street vendors it will also have an impact on increasing regional income and can increase the income per capita in the Brebes area. 


\section{Community Development or Bina Lingkungan}

So far, the notion of the environment is often interpreted as just the physical environment, mainly concerning the preservation of natural resources and the environment (Mehanna \& Mehanna, 2019). But in practice, it is important to realize that the social environment is also very influential in business and life sustainability. It is this kind of awareness that drives the issuance of UU No. 25 of 2007 concerning Investment, and UU No.40 of 2007 concerning the Company, which includes social and environmental responsibility by investment/companies.

Community Development is carried out by the Brebes Regency government to support the activities of street vendors and is a supporter of street vendor empowerment carried out by routine patrols, checking and routine meetings of the community and with the assistance of cooperatives for street vendors supported by the Brebes Regency government who are supported to the maximum extent possible to seek conducive clothing so that Street vendors can develop.

In addition, the Brebes Regency government has issued Regional Regulation No. 1 of 2015 concerning Peace and Public Order. With this regulation, it is expected to discuss a conducive environment for street vendors to carry out their trading activities. Every time, Civil Service Police Brebes as an enforceable local regulation finds street vendors who are difficult to manage.

The cooperative aims to foster and develop and supervise traders in the District of Brebes, especially street vendors, often found to still violate these regulations, according to data obtained by researchers in the field of street vendors who have limited hours of selling from 05.00 WIB until 03.00 WIB often found the street vendors who are still selling until more than 03.00 WIB

Brebes Regency Civil Service Police also makes various efforts so that street vendors obey the rules that have been set, by obeying the regulations that have been set will create a conducive climate for the community and of course for the street vendors themselves.

In addition, the Brebes Regency government in its efforts to develop the environment also utilizes the association of street hawkers who have formed to coordinate between street vendors and the Brebes Regency government. With the regular meeting every two months it is hoped that the coordination of the local government with the street vendors will run well.

This coordination is useful for maintaining good relations between street vendors and local governments, which will have an impact on facilitating local government supervision of street vendors. Formation of street vendors community in Brebes District also serves to maintain the relationship between street vendors with other street vendors. This aims to prevent things that are not desired.

The researcher believes that the empowerment of street vendors conducted by the Brebes Regency government has been going well, but there are still some things that need to be considered in further efforts to empower street vendors in Brebes Regency. Brebes Regency according to the researchers must have special regulations governing efforts to empower street vendors. Not a few districts or cities that already have specific local regulations on empowering street vendors. With the existence of 
special regulations regarding the empowerment of street vendors, it is expected that the empowerment of street vendors in the Brebes District is more directed and structured.

\section{CONCLUSION}

At this part, this paper concludes that the efforts to empower street vendors carried out by the Brebes Regency government are already good, but it would be better if in the efforts to empower street vendors in Brebes District there were special local regulations related to empowering street vendors. The impact of empowering street vendors by the Brebes Regency government is divided into two aspects, namely social and economic aspects. In the social aspect, the impact felt by street vendors is that street vendors do not need to bring merchandise home because the merchandise can be left in shelters, buyers feel comfortable because it is not hot and the environment is more orderly and orderly. The negative impact of some street vendors still selling roadside in front of their shelter. The economic impact is that most street vendors experience an increase in income and regional income also increases. The negative impact is because some street vendors feel their income has decreased with the presence of new street vendors who sell in the area.

Furthermore, based on the results of research on efforts to empower street vendors conducted by the Brebes Regency this research suggests that for street vendors, they should be orderly and obey all rules that have been set by the Brebes Regency government, so that the environment is cleaner, more beautiful, orderly, safe and orderly. The Brebes regional government should develop regional regulations specifically for the empowerment of street vendors so that the empowerment of street vendors is maximized and directed. The government should open a new public area specifically for street vendors to sell. With a neat, orderly, safe and beautiful arrangement so as to provide opportunities for street vendors to improve their economy and can also increase the regional income of Brebes Regency.

\section{REFERENCES}

Alma, B. (2017). Kewirausahaan. Bandung: Alfabeta

Arifin, R., Waspiah, W., \& Latifiani, D. (2018). Penulisan Karya Ilmiah untuk Mahasiswa Hukum. Semarang: BPFH UNNES.

Arifin, R. (2019). Indonesian Political Economic Policy and Economic Rights: An Analysis of Human Rights in the International Economic Law. Journal of Private and Commercial Law, 3(1), 38-49. DOI: https://doi.org/10.15294/jpcl.v3il.18178

Andersen, H. V., \& Pitkänen, K. (2019). Empowering educators by developing professional practice in digital fabrication and design thinking. International Journal of Child-Computer Interaction, 21, 1-16. https://doi.org/10.1016/j.ijcci.2019.03.001 
Bergeron, S., Noskoff, K., Hayakawa, J., \& Frediani, J. (2019). Empowering adolescents and young adults to support, lead and thrive: Development and validation of an AYA Oncology Child Life Program. Journal of Pediatric Nursing, 47, 1-6. https://doi.org/10.1016/j.pedn.2019.04.001

Carmi, N., Alsayegh, M., \& Zoubi, M. (2019). Empowering women in water diplomacy: A basic mapping of the challenges in Palestine, Lebanon, and Jordan. Journal of Hydrology, 569, 330-346. https://doi.org/10.1016/j.jhydrol.2018.12.011

Carroll, S. M. (2019). Respecting and Empowering Vulnerable Populations: Contemporary Terminology. Journal for Nurse Practitioners, 15(3), 228-231. https://doi.org/10.1016/j.nurpra.2018.12.031

Cheong, M., Yammarino, F. J., Dionne, S. D., Spain, S. M., \& ${ }^{2}$ Tsai, C. Y. (2019). A review of the effectiveness of empowering leadership. Leadership Quarterly, 30(1), 34-58. https://doi.org/10.1016/j.leaqua.2018.08.005

Cheung, G., Davies, P. J., \& Trück, S. (2019). Transforming urban energy systems: The role of local governments' regional energy master plan. Journal of Cleaner Production, 220, 655-667. https://doi.org/10.1016/j.jclepro.2019.01.179

Clough Marinaro, I. (2019). Kaleidoscopic shades of grey: The shifting (in)formalities of Rome's street markets. Cities, 95(January), 102413. https://doi.org/10.1016/j.cities.2019.102413

Corwin, S., \& Johnson, T. L. (2019). The role of local governments in the development of China's solar photovoltaic industry. Energy Policy, 130(August 2018), 283-293. https://doi.org/10.1016/j.enpol.2019.04.009

Crittenden, V. L., Crittenden, W. F., \& Ajjan, H. (2019). Empowering women microentrepreneurs in emerging economies: The role of information communications technology. Journal of Business Research, 98(May 2018), 191-203. https://doi.org/10.1016/j.jbusres.2019.01.045

Faiola, A., Papautsky, E. L., \& Isola, M. (2019). Empowering the Aging with Mobile Health: A mHealth Framework for Supporting Sustainable Healthy Lifestyle Behavior. Current Problems in Cardiology, 44(8), 232-266. https://doi.org/10.1016/j.cpcardiol.2018.06.003

Gharaei, A., Karimi, M., \& Hoseini Shekarabi, S. A. (2019). An integrated multiproduct, multi-buyer supply chain under penalty, green, and quality control polices and a vendor managed inventory with consignment stock agreement: The outer approximation with equality relaxation and augmented penalty algorithm. Applied Mathematical Modelling, 69, 223-254. https://doi.org/10.1016/j.apm.2018.11.035 Ghozali, Yusdi. 2011. Pemberdayaan Pedagang Kaki Lima Di Alun-Alun Brebes Kecamatan Brebes Kabupaten Brebes. Mahasiswa Pendidikan Luar Sekolah Fakultas Ilmu Pendidikan Universitas Negeri Semarang.

Handoyo, E. (2013). Kebijakan Publik. Semarang: Widya Karya Hikmat, H. (2017). Strategi Pemberdayaan Masyarakat. Bandung: Alfabeta Higgins, A., Downes, C., Varley, J., Doherty, C. P., Begley, C., \& Elliott, N. (2019). Supporting and empowering people with epilepsy: Contribution of the Epilepsy Specialist Nurses (SENsE study). Seizure, 7l(April), 42-49. https://doi.org/10.1016/j.seizure.2019.06.008 
Jhody, P. S. (2017). Poverty Reduction in Perspective of Public Service Reform: A Study on Legal and Social Analysis (Case of Sragen, Indonesia). JILS (Journal of Indonesian Legal Studies), 2(2), 131-144. https://doi.org/10.15294/jils.v2i02.19435

Kaasinen, E., Schmalfuß, F., Özturk, C., Aromaa, S., Boubekeur, M., Heilala, J., \& Walter, T. (2019). Empowering and engaging industrial workers with Operator 4.0 solutions. Computers and Industrial Engineering, (XXXX), 105678. https://doi.org/10.1016/j.cie.2019.01.052

Kearney, E., Shemla, M., van Knippenberg, D., \& Scholz, F. A. (2019). A paradox perspective on the interactive effects of visionary and empowering leadership. Organizational Behavior and Human Decision Processes, (January), 1-11. https://doi.org/10.1016/j.obhdp.2019.01.001

Lata, L., Walters, P., \& Roitman, S. (2019). A marriage of convenience: Street vendors' everyday accommodation of power in Dhaka, Bangladesh. Cities, 84(December 2017), 143-150. https://doi.org/10.1016/j.cities.2018.08.002

Lee, Y. H., Lu, T. E., Yang, C. C., \& Chang, G. (2019). A multilevel approach on empowering leadership and safety behavior in the medical industry: The mediating effects of knowledge sharing and safety climate. Safety Science, 117(February), 1-9. https://doi.org/10.1016/j.ssci.2019.03.022

Mardiko, T., \& Soebianto, P. (2017). Pemberdayaan Masyarakat dalam Prespektif Kebijakan Publik. Bandung: Alfabeta.

Mehanna, W. A. E. H., \& Mehanna, W. A. E. H. (2019). Urban renewal for traditional commercial streets at the historical centers of cities. Alexandria Engineering Journal. https://doi.org/10.1016/j.aej.2019.09.015

Minister of Domestic Affairs Regulation No. 41 of 2012 concerning Guidelines for Structuring and Empowering Street Vendors

Ojeda, L., \& Pino, A. (2019). Spatiality of street vendors and sociospatial disputes over public space: The case of Valparaíso, Chile. Cities, 95(January), 102275. https://doi.org/10.1016/j.cities.2019.02.005

Pembuain, A., Priyanto, S., \& Suparma, L. B. (2019). The evaluation of tactile ground surface indicator condition and effectiveness on the sidewalk in Yogyakarta City, Indonesia. IATSS Research. https://doi.org/10.1016/j.iatssr.2019.04.002

Peng, Y., Zarringhalam, M., Hajian, M., Toghraie, D., Tadi, S. J., \& Afrand, M. (2019). Empowering the boiling condition of Argon flow inside a rectangular microchannel with suspending Silver nanoparticles by using of molecular dynamics simulation. Journal of Molecular Liquids, 111721. https://doi.org/10.1016/j.molliq.2019.111721

Prabhu, V., Gupta, S. K., Madhwal, S., \& Shridhar, V. (2019). Exposure to Atmospheric Particulates and Associated Respirable Deposition Dose to Street Vendors at the Residential and Commercial Sites in Dehradun City. Safety and Health at Work, 10(2), 237-244. https://doi.org/10.1016/j.shaw.2019.01.005

Richardson-Ngwenya, P., Restrepo, M. J., Fernández, R., \&e Kaufmann, B. A. (2019). Participatory video proposals: A tool for empowering farmer groups in rural innovation processes? Journal of Rural Studies, 69(January), 173-185. https://doi.org/10.1016/j.jrurstud.2019.02.022 
Shiningeni, D., Chimwamurombe, P., Shilangale, R., \& Misihairabgwi, J. (2019). Prevalence of pathogenic bacteria in street vended ready-to-eat meats in Windhoek, Namibia. Meat Science, 148(May), 223-228. https://doi.org/10.1016/j.meatsci.2018.05.014

Suharto, E. 2017. Strategi Pemberdayaan Masyarakat. Bandung: Refika Aditama.

Soon, J. M. (2019). Rapid Food Hygiene Inspection Tool (RFHiT) to assess hygiene conformance index (CI) of street food vendors. Lwt, 113(April), 108304. https://doi.org/10.1016/j.lwt.2019.108304

Regional Regulation Number 1 of 2015 concerning Peace and Public Order

Tatebe, L., Speedy, S., Kang, D., Barnum, T., Cosey-Gay, F., Regan, S., \& Swaroop, M. (2019). Empowering Bystanders to Intervene: Trauma Responders Unify to Empower (TRUE) Communities. Journal of Surgical Research, 238, 255-264. https://doi.org/10.1016/j.jss.2019.02.029

Yakubu Madaki, M., \& Bavorova, M. (2019). Food safety knowledge of food vendors of higher educational institutions in Bauchi state, Nigeria. Food Control, 106(February), 106703. https://doi.org/10.1016/j.foodcont.2019.06.029 